\title{
W/y University of Sunderland
}

Frost, Lisa, Suryadevara, Pratap, Cannell, Stephanie, Groundwater, Paul, Hambleton, Paul and Anderson, Rosaleen (2015) Synthesis of diacylated $\gamma$ glutamyl-cysteamine prodrugs, and in vitro evaluation of their cytotoxicity and intracellular delivery of cysteamine. European Journal of Medicinal Chemistry, 109. pp. 206-215. ISSN 0009-4374

Downloaded from: http://sure.sunderland.ac.uk/id/eprint/5904/

\section{Usage guidelines}

Please refer to the usage guidelines at http://sure.sunderland.ac.uk/policies.html or alternatively contact 
sure@sunderland.ac.uk. 
Eur. J. Med Chem. 109 (2016) 206-215.

Synthesis of diacylated $\gamma$-glutamyl-cysteamine prodrugs, and in vitro evaluation of their cytotoxicity and intracellular delivery of cysteamine

Lisa Frost, Pratap Suryadevara, Stephanie J. Cannell, Paul W. Groundwater ${ }^{\dagger}$, Paul A. Hambleton, Rosaleen J. Anderson*

Sunderland Pharmacy School, University of Sunderland, Sunderland, SR1 3SD, UK

\section{Abstract}

To overcome the major disadvantages of cysteamine, the only registered treatment for the rare genetic disease cystinosis, nine prodrugs of $\gamma$-glutamyl-cysteamine (4) were synthesized for evaluation. Esterification of the thiol conferred oxidative stability, while sufficient lipophilicity for oral bioavailability was achieved by acylation of the $\alpha$-carboxyl group of $\gamma$-glutamyl-cysteamine (4). Low cytotoxicity was observed in cultured HaCaT keratinocytes using the MTT assay, with $\mathrm{EC}_{50}$ values higher than or similar to that of cysteamine. Successful uptake of the esterified prodrugs and the subsequent release of cysteamine into cultured human proximal tubule epithelial cells were demonstrated using CMQT derivatisation and HPLC with UV detection. These prodrugs show potential as novel delivery vehicles of cysteamine to improve the treatment of the genetic disorder nephropathic cystinosis.

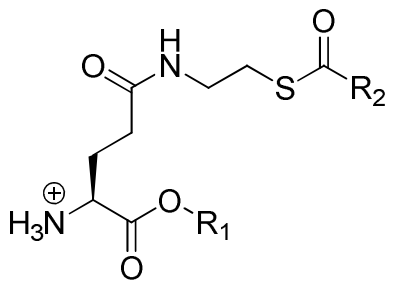

$1-3 a-c$ (i) (Thio)ester hydrolysis
in the blood and/or liver

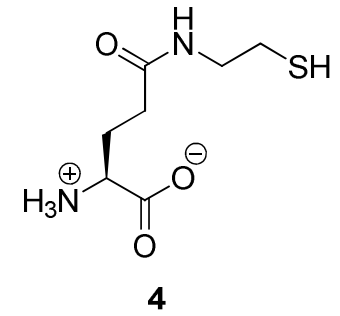

(ii) $\gamma$-glutamyl hydrolysis<smiles>[NH3+]CC[SiH3]</smiles>

Keywords: Nephropathic cystinosis; $\gamma$-glutamyl transpeptidase; cysteamine; cystine; drug targeting; prodrug

\footnotetext{
${ }^{\dagger}$ Present address: Faculty of Pharmacy, University of Sydney, NSW 2006, Australia

*Communicating author: roz.anderson@sunderland.ac.uk
} 
Eur. J. Med Chem. 109 (2016) 206-215.

\section{Introduction}

Nephropathic cystinosis is an autosomal recessive disorder, characterized by the accumulation of cystine crystals within the lysosomes of all cells, as a result of deficiency of the cystine transporter protein. The initial symptoms of cystinosis result from the failure of renal tubules to reabsorb small molecules, causing Fanconi syndrome and the associated polyuria, glucosuria, phosphaturia, and proteinuria [1]. While kidney involvement is one of the classical features of cystinosis, it has been recognized more recently as a multi-systemic disease, due to cystine accumulation in, and damage to, non-renal organs and tissues [1,2]. Untreated, this disease progresses, usually resulting in damage to all organs and death by the age of 10 [3]. Treatment of cystinosis is typically by administration of the aminothiol, cysteamine (as the bitartrate salt, Cystagon $^{\circledR}$, or as its sustained release formulation, Procysbi ${ }^{\circledR}$ ), which reduces lysosomal cystine levels and therefore delays disease progression. However, there are several problems with its administration, which can lead to non-compliance in a large proportion of those affected [4]. Even as the bitartrate salt, cysteamine has an intensely unpleasant taste and smell, resulting in nausea and vomiting [1], and frequently causes disturbance of the gastrointestinal (GI) mucosa; gastric or duodenal ulceration is a common side effect [5]. Extensive first pass metabolism of cysteamine after oral administration leads to urinary excretion of its conjugates, an estimated bioavailability of 10$30 \%$ [2], and significant amounts of dimethyl sulfide and methane thiol exhaled in the breath and through the pores of the skin as body odour [6]. To maintain a therapeutic plasma concentration, 60$90 \mathrm{mg} / \mathrm{kg} /$ day of cysteamine is required in four divided doses [7], reaching $1 \mathrm{~g}$ (as either 50 or 150 mg tablets) per dose for many patients. The importance of a six hourly intake of Cystagon ${ }^{\circledR}$, despite disruption to sleep, was demonstrated by a significant increase in polymorphonuclear cystine levels after 9 hourly dosing, when compared to a six hour dosing interval [8]. The sustained release form Procysbi ${ }^{\circledR}$ allows dosing at 12 hour intervals, alleviating the issue of sleep disturbance, but, as it still releases cysteamine in the GI tract, the problems of first pass metabolism resulting in low 
Eur. J. Med Chem. 109 (2016) 206-215.

bioavailability, the release of strong smelling metabolites, and the gastric disturbance issues are not significantly addressed [9]. Additionally, a cysteamine concentration effect on cell viability and cell proliferation was observed in several cell lines, including cultured human fibroblasts, and excessively high doses of cysteamine have been linked to the appearance of bruise-like lesions on a number of cystinotic patients [10].

Cysteamine is also of interest for its potential in treating other diseases, such as Huntington's disease [11,12], cystic fibrosis [13-15], chronic kidney disease [16], and non-alcoholic fatty liver disease (NAFLD), including non-alcoholic steatohepatitis (NASH) [17]. A current clinical trial is evaluating the potential of Procysbi ${ }^{\circledR}$ as a disease-modifying treatment for Huntington's disease. If the scope of cysteamine as a treatment increases to include these other diseases, similar compliance problems due to its side effects are likely and alternative delivery approaches therefore have wider potential application than to cystinosis alone.

Cysteamine exerts its therapeutic effect due to its ability to undergo a thiol exchange with cystine, resulting in the formation of cysteine and a cysteine-cysteamine mixed disulfide [18] (Scheme 1), which can efflux the lysosome via the transport protein PQLC2. Evidence for the involvement of this transporter in the cysteamine-driven depletion of cystine was obtained by its genetic inactivation or silencing $[19,20]$. Molecular modeling has shown the structural and electronic similarities of the L-cysteine-cysteamine mixed disulfide to L-lysine, facilitating its use of this transporter [21].<smiles>N[C@@H](CSCC([NH3+])C(=O)[O-])C(=O)[O-]</smiles>

Cystine

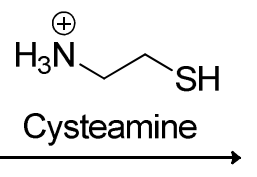

cysteine, both of which can efflux the lysosome

The thiol and amino groups of cysteamine are therefore vital for its role in the treatment of cystinosis, but the unpleasant taste and smell contribute to low levels of patient compliance. Our 
Eur. J. Med Chem. 109 (2016) 206-215.

initial work demonstrated the feasibility of amino acid-cysteamine conjugates as prodrugs, the depletion of cystine providing evidence of their delivery of cysteamine to cystinotic cells, with a delayed response consistent with the requirement for hydrolysis of the amino acid-cysteamine amide bond to release the active agent cysteamine [21]. A major drawback to these simple amino acid-cysteamine derivatives was their lack of clinical relevance; in particular, the thiol group confers nucleophilic and reducing properties, with disulfide bond forming potential, while $\alpha$-amino acid prodrugs are known to be readily hydrolyzed in the blood [22], which would release cysteamine and fail to prevent its metabolism. However, the initial studies also showed good depletion of accumulated cystine in cystinotic cells by $\gamma$-glutamyl-cysteamine, providing evidence of hydrolysis of the $\gamma$-glutamyl amide bond and release of cysteamine, while the $\alpha$-glutamylcysteamine analogue performed poorly in comparison [21]. Initial viability experiments using $\gamma$ glutamyl-cysteamine in cells with a high expression of $\gamma$-glutamyl transpeptidase (GGT), an external cell surface enzyme that recognises and hydrolyses $\boldsymbol{\gamma}$-glutamyl-derivatives, indicated low cytotoxicity [21], providing encouragement for the further development of $\gamma$-glutamyl-cysteamine into a clinical candidate.

\section{Prodrug design and rationale}

Two further groups that are capable of bioactivation were required to convert $\gamma$-glutamylcysteamine into a candidate for clinical use: acylation of the thiol group to confer oxidative stability and an $\alpha$-carboxyl ester to address the likely limitation to oral bioavailability caused by the zwitterionic nature of $\gamma$-glutamyl-cysteamine 4 (Figure 1). These modifications resulted in $S$ thioester and $\alpha$-carboxyl ester $\gamma$-glutamyl-cysteamine derivatives 1a-c, 2a-c, and 3a-c (Figure 1). The combined effects of varied thioester and ester groups enable a limited investigation of suitable prodrug groups with desirable pharmacokinetic and pharmacodynamic properties for the effective treatment of cystinosis by oral administration. Esterification of carboxylic acid, alcohol and thiol groups on pharmaceutical products is a successful strategy to overcome chemical instability and limited oral bioavailability, with convincing evidence from their extensive clinical application [23- 
Eur. J. Med Chem. 109 (2016) 206-215.

25]. Ester prodrugs are hydrolysed rapidly after uptake from the GI tract by blood and liver esterases, human carboxylesterases 1 and 2 (hCE1 and hCE2), with half-lives typically 10-30 minutes [24].
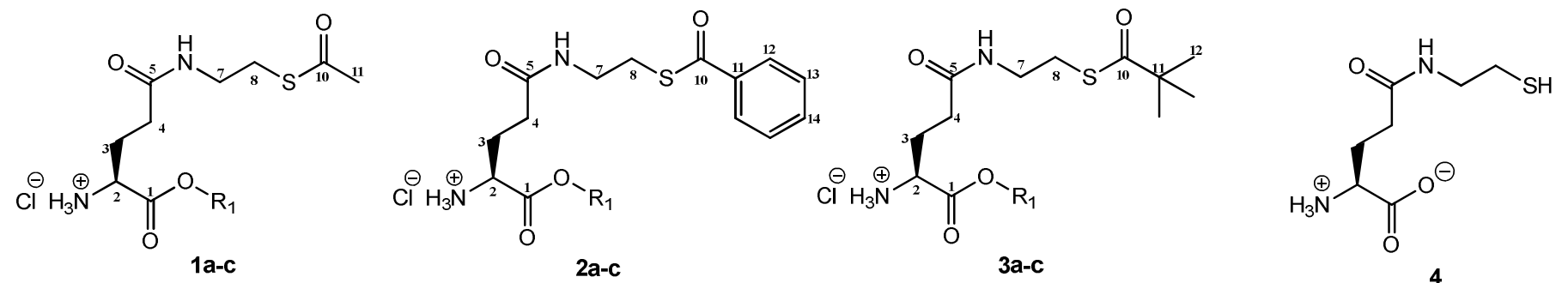

$$
\begin{aligned}
& \text { a } \mathrm{R}_{1}=\mathrm{CH}_{2} \mathrm{CH}_{3} \\
& \text { b } \mathrm{R}_{1}=\mathrm{CH}_{2} \mathrm{CH}_{2} \mathrm{CH}_{3} \\
& \text { c } \mathrm{R}_{1}=\mathrm{CH}_{2} \mathrm{CH}_{2} \mathrm{CH}_{2} \mathrm{CH}_{3}
\end{aligned}
$$

Figure 1: $\gamma$-Glutamyl-cysteamine prodrugs 1a-c, 2a-c and 3a-c and key intermediate $\gamma$-glutamylcysteamine 4

There are three distinct enzyme cleavage steps to release cysteamine from the prodrugs (Scheme 2), presenting two main ways to deliver the active agent cysteamine into cells after absorption from the GI tract. Firstly, satisfactory lipophilicity of the prodrugs permits rapid uptake into cells directly from the blood. Once inside the cells, the prodrugs are hydrolysed to release cysteamine, by thio/esterase activity and hydrolysis of the $\gamma$-glutamyl bond, probably by $\gamma$-glutamyl cyclotransferase. Alternatively, after uptake from the GI tract into the hepatic portal vein, the prodrugs undergo rapid esterase hydrolysis of the $\alpha$-carboxyl ester $\left(R_{1}\right)$ and thioester $\left(R_{2}\right)$ groups in the blood and/or liver to release the key intermediate 4, targeted to $\gamma$-glutamyl transpeptidase (GGT) on the surface of cells. Interaction of $\gamma$-glutamyl-cysteamine 4 with membrane-bound GGT results in the hydrolysis of $\gamma$-glutamyl-cysteamine $\mathbf{4}$ and local release of cysteamine on the surface of the cell, allowing its rapid internalisation. Our previous studies provide evidence for the success of this approach: incubation of cystinotic cells in medium containing $\gamma$-glutamyl-cysteamine 4 resulted in significant depletion of cystine [21]. 


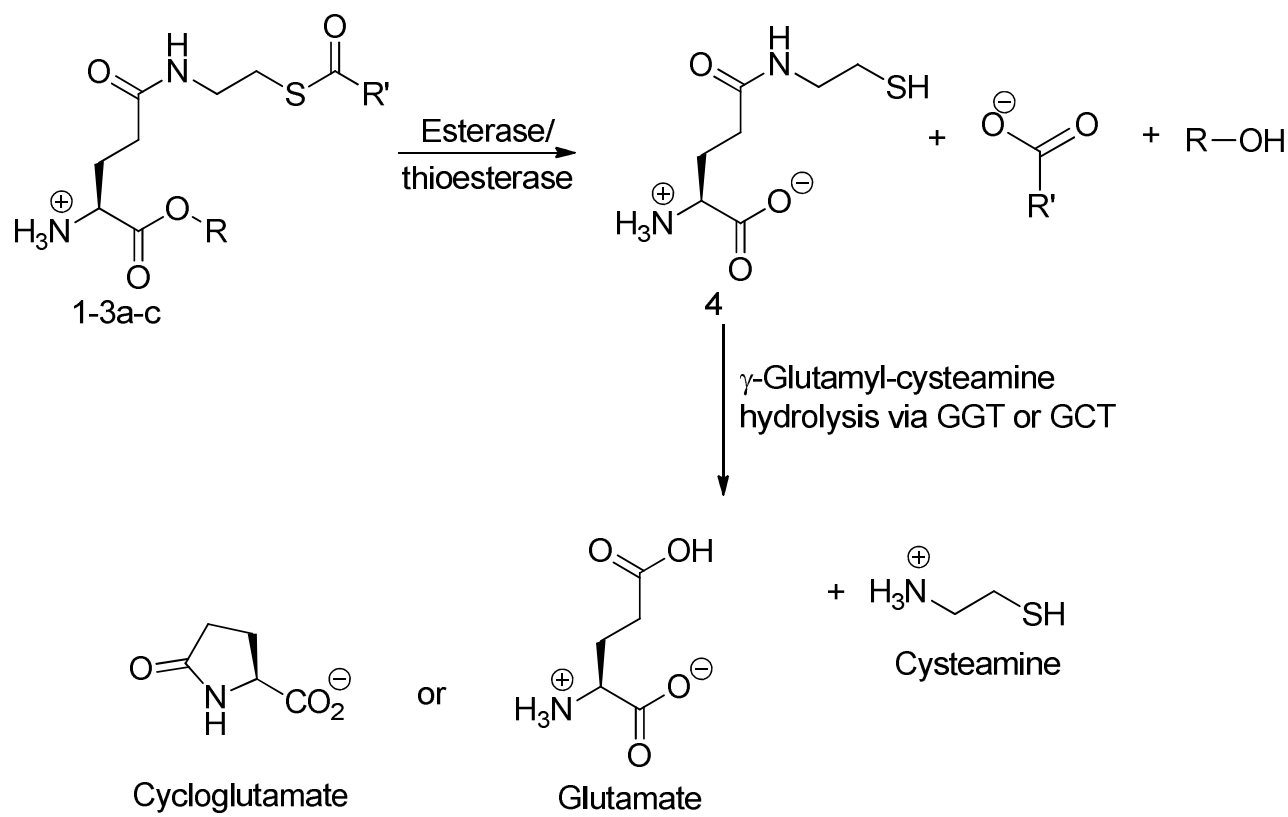

Scheme 2: Sequential enzymatic hydrolysis of $\gamma$-glutamyl-cysteamine prodrugs 1-3a-c to release cysteamine.

Although a low level of serum GGT is normal in humans and is increased in various disease states, such as alcoholic liver disease, the normal activity of serum GGT is around 30 times lower than that of membrane-bound GGT [26] and is likely to make only a small contribution to the release of cysteamine in the circulation. The greater resistance of $\gamma$-glutamyl amide derivatives than their $\alpha$-amide isomers to proteolytic degradation by serum proteases, due to low levels of serum $\gamma$ glutamyl hydrolysis [27], minimizes premature proteolysis of the $\gamma$-glutamyl-cysteamine bond in serum.

GGT is known to recognize a variety of small molecules linked to glutamate via an amide bond at the $\gamma$-carboxyl group [28,29]. It is expressed on the surface of many cells across various tissues, including the proximal convoluted tubule cells of the kidney [30], the intestinal epithelium [31], and the luminal surface of the blood brain barrier [32]; the accumulation of cystine appears to correlate with those cells expressing GGT. The high expression of GGT on renal cells enables increased delivery of cysteamine to these cells, which are the first to display pathology related to cystine accumulation, leading to poor reuptake of essential electrolytes and Fanconi syndrome. In cystinosis, however, cystine accumulates in the majority of cells and tissues throughout the body; the wide expression of GGT on cells and tissues therefore allows delivery of cysteamine to all cells, 
Eur. J. Med Chem. 109 (2016) 206-215.

providing an appropriate multi-systemic treatment for cystinosis. Targeted delivery and GGTmediated release of cysteamine on the surface of cells is expected to result in its rapid uptake into cells in the near vicinity, reducing the amount of free cysteamine released into the circulation and minimizing the opportunity for liver metabolism of cysteamine, maximizing its bioavailability. Benefits would include a less frequent and reduced therapeutic dose, minimizing issues associated with high peak serum cysteamine concentration, including the production of noxious smelling metabolites.

The success of a similar GGT-targeting strategy for the delivery of a cytotoxic glutathione analogue to pancreatic tumours was recently demonstrated [26]. The low serum activity of GGT normally observed in humans resulted in only minimal activation of the antitumour agent systemically. Targeted delivery was also achieved to the kidney with $N$-acyl- $\gamma$-glutamyl prodrugs of sulfamethoxazole [33] and administration of the double prodrug $\gamma$-glutamyl-L-DOPA resulted in a five-fold greater accumulation of renal dopamine than the corresponding dose of the single prodrug L-DOPA [34].

We present here our studies on nine $S$ - and $O$-diacylated $\gamma$-glutamyl-cysteamine prodrugs — their synthesis and the in vitro evaluation of their cytotoxicity, lipophilicity, cellular uptake and hydrolysis to release cysteamine.

\section{Results}

\subsection{Prodrug synthesis}

The synthesis of esterified prodrugs 1a-c, 2a-c and 3a-c was achieved by solution phase peptide coupling (Scheme 3).

$\alpha$-Esterification of commercially sourced benzyl ester $\mathbf{5}$ with the appropriate alkyl bromide under mildly basic conditions gave esters 6a-c in good yield. Palladium-catalyzed reductive deprotection yielded the $\gamma$-carboxylic acids 7a-c, which were coupled with cysteamine using diisopropylcarbodiimide (DIC) and 1-hydroxybenzotriazole (HOBt) to give $\gamma$-glutamyl-cysteamine derivatives 8a-c. 


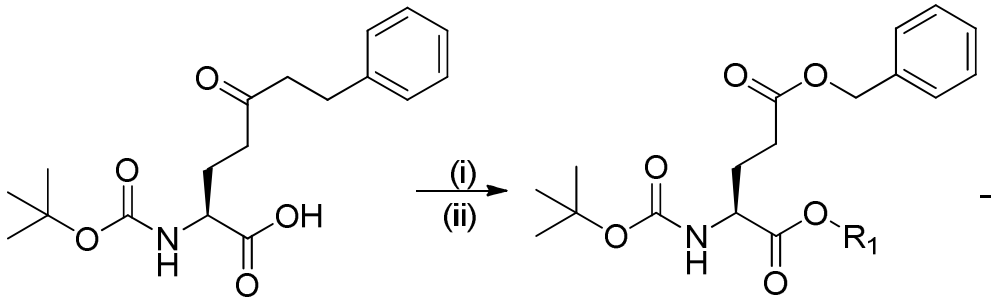

5
$6 a(91 \%)$ $6 b(90 \%)$ $6 c(85 \%)$<smiles>[R]OC(=O)[C@H](CCC(=O)O)NC(=O)OC(C)(C)CC(C)C</smiles>

$7 a(95 \%)$ $7 \mathrm{~b}(90 \%)$ 7c (89 \%) (iv)<smiles>[R]OC(=O)[C@H](N)CCC(=O)NCCSC([R])=O</smiles>

\begin{tabular}{c|c|c}
\hline Compound & $\mathbf{R}_{2}$ & Yields \\
\hline $\mathbf{1}$ & $\mathrm{CH}_{3}$ & $\mathbf{1 a}(81 \%), \mathbf{1 b}(79 \%), \mathbf{1 c}(67 \%)$ \\
\hline $\mathbf{2}$ & $\mathrm{Ph}$ & $\mathbf{2 a}(67 \%), \mathbf{2 b}(52 \%), \mathbf{2 c}(94 \%)$ \\
\hline $\mathbf{3}$ & $\left(\mathrm{CH}_{3}\right)_{3}$ & $\mathbf{3 a}(71 \%), \mathbf{3 b}(88 \%), \mathbf{c}(71 \%)$ \\
\hline $\mathbf{9}$ & $\mathrm{CH}_{3}$ & $\mathbf{9 a}(34 \%), \mathbf{9 b}(62 \%), \mathbf{c}(56 \%)$ \\
\hline $\mathbf{1 0}$ & $\mathrm{Ph}$ & $\mathbf{1 0 a}(25 \%), \mathbf{1 0 b}(24 \%), \mathbf{1 0 c}(47 \%)$ \\
\hline $\mathbf{1 1}$ & $\left(\mathrm{CH}_{3}\right)_{3}$ & $\mathbf{1 1 a}(56 \%), \mathbf{1 1 b}(43 \%), \mathbf{1 1}(40 \%)$ \\
\hline
\end{tabular}

Scheme 3: General synthetic pathway to esterified prodrugs 1a-c, 2a-c and 3a-c.

Reagents and conditions: (i) $\mathrm{MeOH} / \mathrm{H}_{2} \mathrm{O}, \mathrm{Cs}_{2} \mathrm{CO}_{3}$, RT, 24 h; (ii), R-Br, DMF, RT, 24 h; (iii), $\mathrm{Pd}-\mathrm{C}, \mathrm{H}_{2}, \mathrm{MeOH}, \mathrm{RT}, 3$ h; (iv) Diisopropylcarbodiimide, HOBt, cysteamine hydrochloride, $\mathrm{Et}_{3} \mathrm{~N}, \mathrm{DCM}, 0^{\circ} \mathrm{C}-\mathrm{RT}, 24 \mathrm{~h}$; (v) acetic anhydride, $\mathrm{Et}_{3} \mathrm{~N}, \mathrm{THF}, 40^{\circ} \mathrm{C}, 24 \mathrm{~h}$; (vi) benzoyl chloride, pyridine, DCM, RT, $24 \mathrm{~h}$; (vii) pivaloyl chloride, pyridine, DCM, RT, 24 h; (viii) $\mathrm{HCl}(2 \mathrm{M})$ in diethyl ether, $\mathrm{RT}$.

Thioesters 9a-c were formed using acetic anhydride and triethylamine, while thioesters 10ac and 11a-c were prepared using benzoyl chloride or pivaloyl chloride, as appropriate, and pyridine. $t$-Boc deprotection of compounds 9-11 using hydrochloric acid (2M) in diethyl ether gave the nine target esterified prodrugs 1a-c, 2a-c and 3a-c, respectively. 
Eur. J. Med Chem. 109 (2016) 206-215.

\subsection{Cytotoxicity Studies}

Despite its limitations, the MTT assay allows early identification of cytotoxic or other adverse cellular effects. Initial cytotoxicity studies on esterified prodrugs 1a-c, 2a-c and 3a-c, compared to cysteamine hydrochloride, were carried out using spontaneously transformed keratinocytes from histologically normal skin (HaCaT) using a standard MTT assay, in which yellow MTT (3-(4,5-dimethylthiazol-2-yl)-2,5-diphenyltetrazolium bromide) is reduced to purple formazan in metabolically active cells [35]. Percentage survival value at each concentration was derived from the data of 12 replicates, which were averaged and normalised to calculate the percentage survival. In this work, the results of the in vitro tests are expressed as $\mathrm{EC}_{50}$, which represents the mean dose required to kill half of the members of a test in vitro population. The $\mathrm{EC}_{50}$ values (calculated using GraphPad Prism ${ }^{\circledR}$ ) for $\gamma$-glutamyl-cysteamine prodrugs and cysteamine hydrochloride (Table 1) represent the dose required to kill $50 \%$ of the cells.

Table 1: Mean $(n=12) \mathrm{EC}_{50}$ values $( \pm$ standard error) of esterified $\gamma$-glutamyl-cysteamine prodrugs 1a-c, $2 \mathrm{a}$-c and 3a-c and cysteamine hydrochloride in cultured HaCaT keratinocytes.

\begin{tabular}{c|c|c|c|c|c|c|c|c|c|c}
\hline Compound & $\mathbf{1 a}$ & $\mathbf{1 b}$ & $\mathbf{1 c}$ & $\mathbf{2 a}$ & $\mathbf{2 b}$ & $\mathbf{2 c}$ & $\mathbf{3 a}$ & $\mathbf{3 b}$ & $\mathbf{3 c}$ & $\begin{array}{c}\text { Cysteamine. } \\
\text { HCl }\end{array}$ \\
\hline $\mathbf{E C}_{\mathbf{5 0}}(\boldsymbol{\mu M})$ & 1732 & 548 & 563 & 331 & 75 & 97 & 228 & 152 & 102 & 309 \\
& $(3.74)$ & $(3.21)$ & $(3.22)$ & $(2.74)$ & $(2.84)$ & $(3.19)$ & $(3.03)$ & $(10.00)$ & $(10.31)$ & $(9.82)$ \\
\hline
\end{tabular}

The range of $\mathrm{EC}_{50}$ values across the prodrugs underlines the importance of the correct choice of thioester and ester groups. In each thioester series, the ethyl esters (1a, $\mathbf{2 a}$ and $\mathbf{3 a}$ ) showed lower cytotoxicity than their propyl and butyl analogues. It is unlikely that these differences are caused by differential uptake of the prodrugs due to the lipophilicity of the ester groups, as the efficient uptake of all members of the $1^{\text {st }}$ series $(\mathbf{1 a}, \mathbf{1 b}$ and $\mathbf{1 c})$ was confirmed in subsequent experiments, when the intracellular cysteamine levels achieved by ethyl ester 1a were comparable to those achieved by propyl ester $\mathbf{1 b}$ and butyl ester $\mathbf{1 c}$ (Figure 2). The relatively low cytotoxicity of acetyl thioester prodrugs 1a-c and ethyl esters 2a and 3a led to selection of these prodrugs for progression to further studies designed to evaluate the uptake of these ester/thioester prodrugs of $\gamma$ - 
Eur. J. Med Chem. 109 (2016) 206-215.

glutamyl-cysteamine $\mathbf{4}$ into cultured cell lines and their subsequent intracellular hydrolysis to release cysteamine. Ethyl ester prodrug 3a was included for testing, even though it showed greater cytotoxicity than cysteamine hydrochloride, to provide an example from each series.

\subsection{Physicochemical properties of esterified prodrugs}

The oral bioavailability of pharmaceuticals is heavily influenced by the balance of aqueous solubility and lipophilicity, which are affected by the $\mathrm{p} K_{\mathrm{a}}$ of any ionisable groups and the consequent $\log \mathrm{P}$ of the molecule at physiological $\mathrm{pH}$ values. Early investigation of these properties is therefore desirable.

Experimentally measured $\mathrm{p} K_{\mathrm{a}}$ and $\log \mathrm{P}$ values $(\mathrm{M} \log \mathrm{P})$ were obtained using a Sirius $\mathrm{T} 3$ and compared with the calculated $\log \mathrm{P}$ values $\left(\mathrm{Clog} \mathrm{P}\right.$; ChemDraw $\left.{ }^{\circledR}\right)$ and the $\log \mathrm{D}$ values (derived from the Sirius T3 experimental data (Equation 1)) at pH 7.4 (Table 2).

$$
\log D=\log P-\log \left(1+10^{(p K a-p H)}\right)
$$
Equation 1

Table 2: Measured $\mathrm{p} K_{\mathrm{a}}$ ( \pm standard error), calculated $\log \mathrm{P}\left(\mathrm{Clog} \mathrm{P}, \mathrm{ChemDraw}{ }^{\circledR}\right)$, measured $\log \mathrm{P}$ values (MlogP) and $\log \mathrm{D}$ values (triplicate measurements) of ester/thioester $\gamma$-glutamyl cysteamine prodrugs 1a-c, 2a and 3a, compared to cysteamine hydrochloride and cystamine dihydrochloride.

\begin{tabular}{|c|c|c|c|c|c|c|}
\hline Prodrug & $\mathbf{R}$ & $\mathbf{R}^{\prime}$ & $\begin{array}{c}\mathrm{p} K_{\mathrm{a}} \\
\text { (experimental) }\end{array}$ & ClogP & $M \operatorname{logP}$ & $\log$ D at pH7.4 \\
\hline $1 \mathbf{a}$ & $\mathrm{CH}_{2} \mathrm{CH}_{3}$ & $\mathrm{CH}_{3}$ & $8.94( \pm 0.29)$ & -0.98 & +0.11 & -1.44 \\
\hline $1 \mathrm{~b}$ & $\left(\mathrm{CH}_{2}\right)_{2} \mathrm{CH}_{3}$ & $\mathrm{CH}_{3}$ & $8.80( \pm 0.20)$ & -0.52 & +0.21 & -1.21 \\
\hline $1 \mathrm{c}$ & $\left(\mathrm{CH}_{2}\right)_{3} \mathrm{CH}_{3}$ & $\mathrm{CH}_{3}$ & $8.69( \pm 0.18)$ & -0.07 & +0.43 & -0.88 \\
\hline $2 \mathbf{a}$ & $\mathrm{CH}_{2} \mathrm{CH}_{3}$ & $\mathrm{Ph}$ & $8.85( \pm 0.38)$ & +0.31 & +1.09 & -0.37 \\
\hline $3 a$ & $\mathrm{CH}_{2} \mathrm{CH}_{3}$ & $\left(\mathrm{CH}_{3}\right)_{3}$ & $8.90( \pm 0.36)$ & +0.48 & +1.22 & -0.29 \\
\hline $\begin{array}{c}\text { Cysteamine } \\
\mathrm{HCl}\end{array}$ & - & - & $\begin{array}{l}8.15( \pm 0.15 \text { thiol }) \\
10.52( \pm 0.40 \text { amine })\end{array}$ & -0.1 & +0.06 & -2.28 \\
\hline $\begin{array}{c}\text { Cystamine } \\
\text { dihydrochloride }\end{array}$ & - & - & $9.11( \pm 0.12)$ & -0.74 & -0.46 & -2.18 \\
\hline
\end{tabular}


Eur. J. Med Chem. 109 (2016) 206-215.

The measured $\mathrm{p} K_{\mathrm{a}}$ values indicate that the prodrugs are likely to remain largely ionized throughout the GI tract after oral administration, with up to $20 \%$ unionized amine present in the small intestine to facilitate absorption. Both the measured and calculated $\log \mathrm{P}$ values increased in parallel with homologation of the $\alpha$-ester and variation of the thioester group. Although not optimal, these characteristics are comparable to many orally administered agents in clinical use and are consistent with the aim of designing prodrugs with clinical potential for oral administration.

\subsection{In vitro studies}

Provided cysteamine is not significantly released from the prodrugs during incubation in the medium, successful cellular uptake and hydrolysis of the prodrugs can be demonstrated by measuring the increased levels of intracellular cysteamine. The possibility of prodrug hydrolysis in fetal bovine serum-containing medium was investigated in separate experiments using prodrug 1a and $\gamma$-glutamyl-cysteamine 4 with LC-MS analysis. Slow hydrolysis of the thioester and, to a lesser extent, the $\alpha$-carboxyl ester was observed, but the $\gamma$-glutamyl-cysteamine bond was not cleaved over 24 hours (data not shown). It was concluded that hydrolysis of the prodrug to release cysteamine by the action of serum esterase and GGT in the culture medium was unlikely.

Exposure of cultured cells to the prodrugs, followed by measurement of the resulting intracellular cysteamine concentrations, allowed the investigation of three indicators: the uptake of prodrugs into the cells, the successful ester/thioester hydrolysis of the prodrugs, and the release of cysteamine from $\gamma$-glutamyl-cysteamine 4. Following treatment of cultured proximal tubule epithelial cells with test agents, the intracellular cysteamine concentration was quantified using 2chloro-1-methylquinolinium tetrafluoroborate (CMQT) as a pre-column derivatising agent and HPLC. CMQT reacts instantaneously and highly specifically with thiols, under mild conditions, to form a thiol-CMQT derivative that can be quantified using HPLC with ultraviolet or fluorescent detection [34]. HPLC conditions, equipment and validation data are included in the Supporting Information. 
Eur. J. Med Chem. 109 (2016) 206-215.

\subsubsection{Prodrug uptake and cysteamine release in proximal tubular cells}

A normal cultured human proximal tubular (kidney) cell line, PT37 [37], was used to assess the cellular uptake and release of cysteamine from esterified prodrugs 1a-c, 2a and 3a, using cysteamine and its disulfide cystamine as controls. The concentration of $20 \mu \mathrm{M}$ prodrug was chosen to mimic cysteamine levels in the blood of patients treated with Cystagon ${ }^{\circledR}$ and is in line with the established $\mathrm{EC}_{50}$ of $12.5 \mu \mathrm{M}$ [7]. Following prodrug exposure, the intracellular concentration of cysteamine was measured after cell lysis, centrifugation and Bradford assay of the pellet protein content, supernatant thiol derivatization with the tagging agent CMQT, followed by HPLC analysis using simultaneous UV and fluorescence detection, Figure 2.

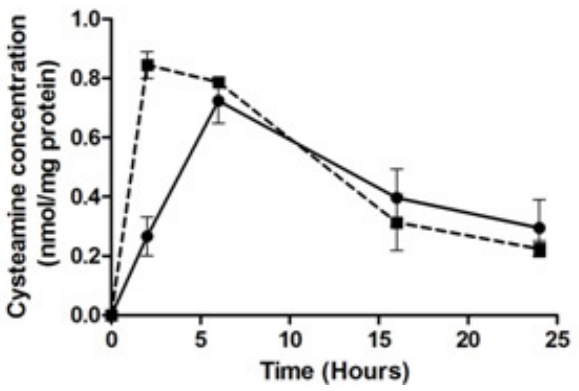

Prodrug 1a

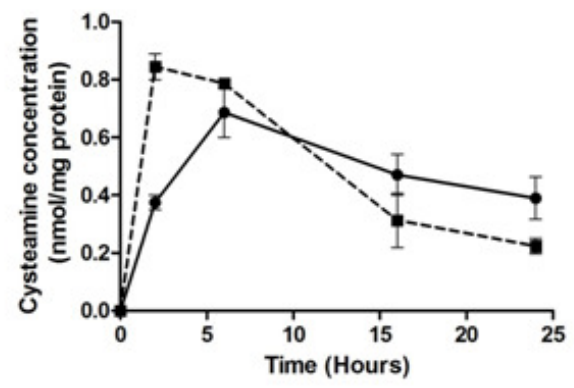

Prodrug 1c

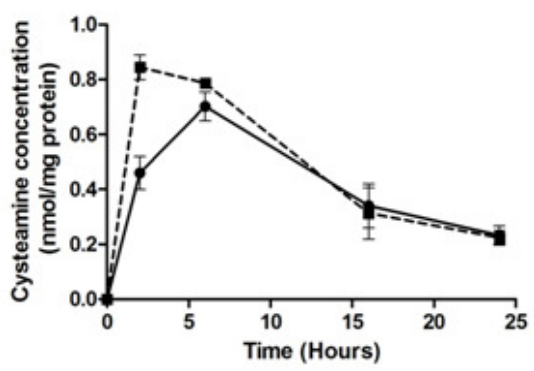

Prodrug 3a

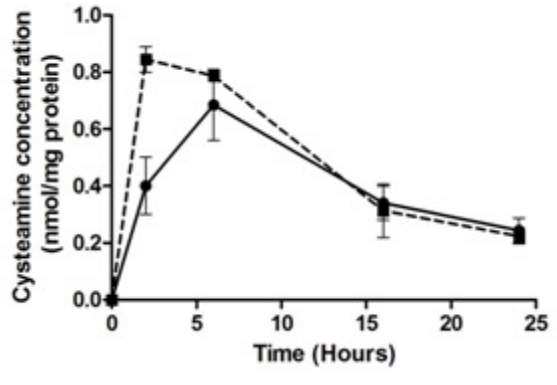

Prodrug 1b

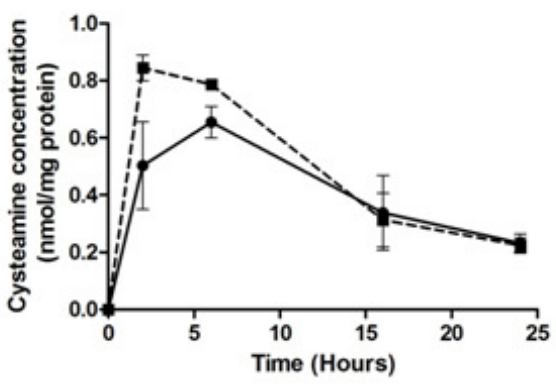

Prodrug 2a

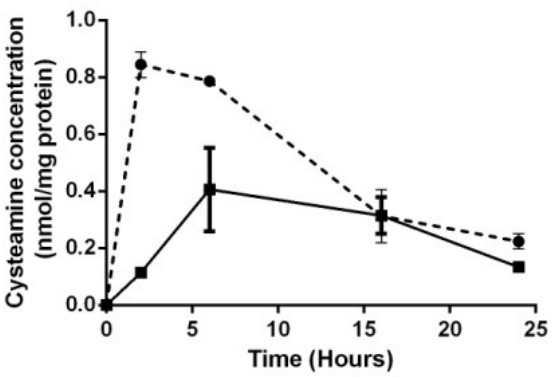

Cystamine dihydrochloride 
Eur. J. Med Chem. 109 (2016) 206-215.

Figure 2: Cysteamine concentration in PT37 cells treated with $20 \mu \mathrm{M}$ prodrugs 1a-c, 2a, 3a or cystamine dihydrochloride, each in comparison to cysteamine hydrochloride (dashed line). Each point represents mean concentration $(n=3)$ and error bars represent standard error.

Analysis of untreated PT37 cells showed no cysteamine-CMQT peak, indicating an initial intracellular cysteamine concentration below the level of detection $(<160 \mathrm{nM})$. Cysteamine uptake into cells following treatment with cysteamine hydrochloride was confirmed by the detection of cysteamine-CMQT. Cysteamine uptake was rapid, peaking after two hours; the level was maintained at $0.84 \pm 0.06 \mathrm{nmol} / \mathrm{mg}$ protein until around 6 hours, dropping to $0.22 \pm 0.04 \mathrm{nmol} / \mathrm{mg}$ protein after 24 hours, suggesting that cysteamine is metabolized after internalization. The intracellular level of cysteamine did not continue to rise when its concentration was maintained in the medium at $20 \mu \mathrm{M}$, supporting the observation that cysteamine uptake may be saturable [38].

When exposed to air, cysteamine is rapidly oxidized to its disulfide form, cystamine [39], particularly when in dilute aqueous solution. The rate of oxidation of cysteamine hydrochloride in aqueous solution was investigated by HPLC with UV detection, using pre-analysis derivatisation by CMQT. Only the reduced thiol form can react with CMQT and is selectively detected, Figure 3.

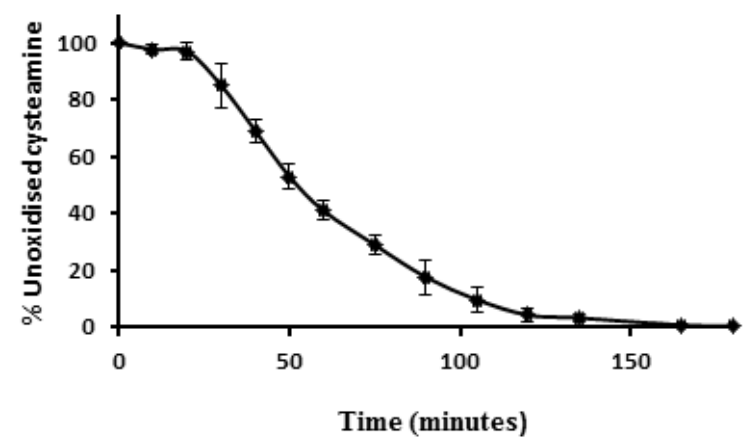

Figure 3: Oxidation of cysteamine (0.01 M cysteamine hydrochloride in water, room temperature, in triplicate); detected as the CMQT derivative using HPLC with UV detection.

The oxidation of cysteamine hydrochloride in water ( $\mathrm{pH} 4.66$ ) occurred rapidly, falling to $50 \%$ within 1 hour; after approximately 3 hours, there was no detectable cysteamine in the solution. When PT37 cells were treated directly with the disulfide, cystamine dihydrochloride, the total intracellular levels of cysteamine were considerably lower than those observed when the same cells 
Eur. J. Med Chem. 109 (2016) 206-215.

were treated with cysteamine hydrochloride; the dicationic hydrophilic nature of cystamine is likely to hinder uptake into the cell and the efficiency of its intracellular bioreduction has not been established, thus cystamine has not found application for the treatment of cystinosis. In addition to extensive first pass metabolism, oxidation to the disulfide may be partly responsible for the poor bioavailability of cysteamine in the therapy of cystinosis. A number of thioesters of cysteamine were synthesized and showed significantly increased stability to oxidation compared to cysteamine (data not shown). The use of thioester groups in the prodrugs inhibits oxidation of the free thiol to the disulfide with the aim of increasing cysteamine bioavailability.

Cysteamine-CMQT was also observed when cells were treated with any of prodrugs 1a-c, 2a and 3a, providing evidence for their uptake and hydrolysis to release cysteamine. Peak levels of cysteamine were not reached until 6 hours after exposure, consistent with the requirement for enzymatic action on the $\alpha$-carboxyl ester, thioester, and $\gamma$-glutamyl groups to release cysteamine. In agreement with the measured $\log \mathrm{P}$ values (Table 2), the $S$-acetyl prodrugs 1a-c (with lower MlogP values) were associated with a slower increase in cysteamine concentration than the $S$-benzoyl 2 a and $S$-pivaloyl 3a prodrugs (with higher MlogP values and greater lipophilicity). In this instance, due to the minimal hydrolysis of esters in the culture medium, it is probable that the ester/thioester prodrugs were internalised by passive diffusion, with no involvement of GGT, and broken down intracellularly to release cysteamine.

\section{Conclusion}

Nine esterified $\gamma$-glutamyl-cysteamine prodrugs were designed to overcome some of the undesirable properties of the pharmaceutical product cysteamine. Derivatization as the $\gamma$ glutamyl-derivative was successful, offering increased metabolic stability, and physicochemical properties suitable for oral bioavailability were achieved by esterification of the glutamate $\alpha$ carboxyl group, while oxidation of the thiol was inhibited by thioester formation. In addition, particularly low cytotoxicity of $\mathbf{1 a}, \mathbf{1 b}$ and $\mathbf{1 c}$ in HaCaT keratinocytes was observed using the MTT 
Eur. J. Med Chem. 109 (2016) 206-215.

assay; $\alpha$-ethyl esters $\mathbf{2 a}$ and 3a showed similar cytotoxicity to that of cysteamine in this system, while acetyl thioesters 1a-c exhibited lower cytotoxicity than cysteamine. These ester/thioester $\gamma$ glutamyl-cysteamine prodrugs displayed uptake into cells, ester and thioester hydrolysis, and release of cysteamine, with a delay to its release consistent with the requirement for activation of the prodrug. Furthermore, the prodrugs maintained the concentration of cysteamine at above baseline levels for at least 24 hours, comparative to or better than that achieved by cysteamine hydrochloride and significantly better than that achieved by cystamine dihydrochloride. These data support the in vivo efficacy evaluation of cysteamine prodrugs in a validated animal model for their potential as an alternative oral treatment for cystinosis.

This targeted prodrug approach to the delivery of cysteamine may also have application to the treatment of other diseases, such as Huntington's disease, cystic fibrosis and non-alcoholic steatohepatitis (NASH), in which recent research has demonstrated a beneficial effect of cysteamine.

\section{Experimental}

Supporting Information available: general methods and examples are shown in this section. Full experimental data are available as Supporting Information.

The structures of products were assigned using IR, ${ }^{1} \mathrm{H}$ NMR and ${ }^{13} \mathrm{C}$ NMR spectroscopy, including 2D techniques (COSY, HMQC, HMBC), and by mass spectrometry. The purity of products was confirmed as $>95 \%$ using elemental analysis, HPLC with UV detection, or LC-MS. Unless stated otherwise, all chemicals and solvents were obtained from Sigma Aldrich (UK) and used without further purification. Solvents were dried using the Pure Solv ${ }^{\mathrm{TM}}$ purification system (Innovative Technology, Inc). TLC was carried using silica gel matrix on aluminium foil (Sigma Aldrich). Column chromatography used silica gel, particle size 35-70 micron (Fisher Scientific). CHN analysis, NMR spectroscopy and mass spectrometry were carried out using, respectively, an Exeter Analytical CE 440 Elemental Analyzer instrument, AVANCE DPX 300MHz Bruker NMR 
Eur. J. Med Chem. 109 (2016) 206-215.

instrument at $300 \mathrm{MHz}\left({ }^{1} \mathrm{H}\right)$ or $75 \mathrm{MHz}\left({ }^{13} \mathrm{C}\right)$ and an Esquire $3000+$ Ion Trap mass spectrometer. IR spectroscopy was carried out with a Perkin Elmer Spectrum BX FT-IR system. Melting point determination was carried out using a Stuart SMP 30 melting point apparatus. ESI HRMS was performed courtesy of the EPSRC National Mass Spectrometry Service Centre.

\subsection{General method for preparation of compounds $6 \mathbf{a - c}$}

2-(S)-tert-Butoxycarbonylamino-pentanedioic acid 5-benzyl ester $\mathbf{5}$ was dissolved in methanol with $10 \%$ water $(10 \mathrm{~mL})$. The solution was neutralized to $\mathrm{pH} 7$ by drop-wise addition of aqueous $\mathrm{Cs}_{2} \mathrm{CO}_{3}(20 \%)$. Following evaporation under high vacuum, the resulting syrup was dissolved in dry DMF $(20 \mathrm{~mL})$ and treated with the appropriate alkyl bromide (2.88 molar equivalents). The reaction was stirred at room temperature overnight. Ethyl acetate $(20 \mathrm{~mL})$ was added and the organic layer washed with water $(3 \times 20 \mathrm{~mL}), 10 \% \mathrm{~K}_{2} \mathrm{CO}_{3}(2 \times 20 \mathrm{~mL})$, and brine (20 mL), and then dried over magnesium sulfate. The resulting solution was concentrated under reduced pressure to afford the product as a white solid.

\subsubsection{2-(S)-tert-Butoxycarbonylamino-pentanedioic acid 5-benzyl ester 1-propyl ester (6b)}

Following the procedure described in 4.1, the reaction of 2-tert-butoxycarbonylaminopentanedioic acid 5-benzyl ester 5 (1.00 g, $2.96 \mathrm{mmol})$ with propyl bromide (1.05 $\mathrm{mL}, 8.52 \mathrm{mmol})$ gave product $6 \mathbf{b}(1.01 \mathrm{~g}, 90 \%): \mathrm{Mp} 51-52{ }^{\circ} \mathrm{C} ;{ }^{1} \mathrm{H}$ NMR $\left(300 \mathrm{MHz}, \mathrm{CDCl}_{3}\right) \delta_{\mathrm{H}} 0.95(\mathrm{t}, J=7.1 \mathrm{~Hz}$, $\left.3 \mathrm{H}, 3^{\prime}-\mathrm{CH}_{3}\right), 1.43\left(\mathrm{~s}, 9 \mathrm{H}, t-\mathrm{Boc}_{\mathrm{CH}}\right), 1.68$ (sextet, $\left.J=7.1 \mathrm{~Hz}, 2 \mathrm{H}, 2^{\prime}-\mathrm{CH}_{2}\right), 1.96\left(\mathrm{~m}, 1 \mathrm{H}, 3-\mathrm{CH}_{\mathrm{a}}\right)$, $2.21\left(\mathrm{~m}, 1 \mathrm{H}, 3-\mathrm{CH}_{\mathrm{b}}\right), 2.41\left(\mathrm{dd}, J=16.5\right.$ and $\left.6.8 \mathrm{~Hz}, 1 \mathrm{H}, 4-\mathrm{CH}_{\mathrm{a}}\right), 2.50(\mathrm{dd}, J=16.5$ and $6.8 \mathrm{~Hz}, 1 \mathrm{H}$, 4- $\left.\mathrm{CH}_{\mathrm{b}}\right), 4.09\left(\mathrm{t}, J=7.1 \mathrm{~Hz}, 2 \mathrm{H}, 1^{\prime}-\mathrm{CH}_{2}\right), 4.33(\mathrm{~m}, 1 \mathrm{H}, 2-\mathrm{CH}), 5.08(\mathrm{br} \mathrm{d}, 1 \mathrm{H}, \mathrm{NH}), 5.12(\mathrm{~s}, 2 \mathrm{H}$, $\mathrm{CH}_{2} \mathrm{Ph}$ ), 7.35 (m, 5H, $\left.\mathrm{CH}_{2} \mathrm{Ph}\right) ;{ }^{13} \mathrm{C}$ NMR (75 MHz, $\mathrm{CDCl}_{3}$ ) $\delta_{\mathrm{C}} 10.3$ (3'-C), 21.9 (2'-C), 28.0 (3-C), $28.3\left(t-\mathrm{Boc} \mathrm{CH}_{3}\right), 30.4$ (4-C), 53.0 (2-C), 62.1 (1'-C), $66.5\left(\mathrm{CH}_{2} \mathrm{Ph}\right), 80.0$ (quat., $t$-Boc C), $128.3(\mathrm{Ph}$ $\mathrm{CH}$ ), 128.3 (Ph CH), 128.6 (Ph CH), 135.9 (quat., $\mathrm{Ph} \mathrm{C}$ ), 155.4 (quat., $\mathrm{NCO}_{2}$ ), 172.2 (quat., 5-C), 172.5 (quat., 1-C); IR cm $3361(\mathrm{~N}-\mathrm{H}), 1760(\mathrm{C}=\mathrm{O}$, ester), $1720(\mathrm{C}=\mathrm{O}$, ester), $1686(\mathrm{C}=\mathrm{O}$, 
Eur. J. Med Chem. 109 (2016) 206-215.

carbamate), $1365(\mathrm{C}-\mathrm{N}), 1169(\mathrm{C}-\mathrm{O}), 750,698(\mathrm{Ar} \mathrm{C}-\mathrm{H})$; Anal. calculated for $\mathrm{C}_{20} \mathrm{H}_{29} \mathrm{NO}_{6}\left(\mathrm{M}_{\mathrm{r}}\right.$ 379.45) C 63.31, H 7.70, N 3.69 \%; Found C 63.51, H 7.68, N $3.73 \%$; ESI MS 401.1 [MNa ${ }^{+}$.

\subsection{General method for preparation of compounds $7 a-c$}

Compounds 6a-c were dissolved in methanol $(50 \mathrm{~mL})$. Palladium on carbon $(10 \%$, Alfa Aesar) was added (0.1 mass equivalent) and the mixture was stirred for approximately 3 hours, at room temperature, under a hydrogen atmosphere at 3 bars of pressure. The catalyst was removed by filtration over celite and the resulting solution was concentrated under reduced pressure to afford a colourless oil, which was dissolved in a minimum amount of ethyl acetate, and then hexane was added until the solution became turbid. The solution was stored at $0^{\circ} \mathrm{C}$ overnight and the resultant precipitate was collected by filtration.

\subsubsection{2-(S)-tert-Butoxycarbonylamino-pentanedioic acid 1-butyl ester (7c)}

Following the procedure described in 4.2 , compound $\mathbf{6 c}(2.0 \mathrm{~g}, 5.08 \mathrm{mmol})$ was reduced to give product 7c $(1.377 \mathrm{~g}, 89 \%)$ : Mp 52-54 ${ }^{\circ} \mathrm{C} ;{ }^{1} \mathrm{H}$ NMR $\left(300 \mathrm{MHz}, \mathrm{CDCl}_{3}\right) \delta_{\mathrm{H}} 0.92(\mathrm{t}, J=7.1 \mathrm{~Hz}, 3 \mathrm{H}$, 4'- $\mathrm{CH}_{3}$ ) 1.36 (sextet, $J=7.1 \mathrm{~Hz}, 2 \mathrm{H}, 3^{\prime}-\mathrm{CH}_{2}$ ) $1.43\left(\mathrm{~s}, 9 \mathrm{H}, t-\mathrm{Boc}_{\mathrm{CH}}\right.$ ), 1.62 (quintet, $J=6.5 \mathrm{~Hz}$, $\left.2 \mathrm{H}, 2^{\prime}-\mathrm{CH}_{2}\right), 1.95\left(\mathrm{~m}, 1 \mathrm{H}, 3-\mathrm{CH}_{\mathrm{a}}\right), 2.15\left(\mathrm{~m}, 1 \mathrm{H}, \mathrm{m}, 3-\mathrm{CH}_{\mathrm{b}}\right), 2.41(\mathrm{dd}, J=16.7$ and $6.9 \mathrm{~Hz}, 1 \mathrm{H}, 4-$ $\left.\mathrm{CH}_{\mathrm{a}}\right), 2.51\left(\mathrm{dd}, J=16.7\right.$ and $\left.6.9 \mathrm{~Hz}, 1 \mathrm{H}, 4-\mathrm{CH}_{\mathrm{b}}\right), 4.13\left(\mathrm{t}, J=6.5 \mathrm{~Hz}, 2 \mathrm{H}, 1^{\prime}-\mathrm{CH}_{2}\right), 4.30(\mathrm{~m}, 1 \mathrm{H}, 2-$

$\mathrm{CH}), 5.24$ (br d, 1H, NH); ${ }^{13} \mathrm{C}$ NMR $\left(75 \mathrm{MHz}, \mathrm{CDCl}_{3}\right.$ ) $\delta_{\mathrm{C}} 13.6$ (4'-C), 19.0 (3'-C), 27.7 (3-C), 28.2 ( $t$-Boc $\mathrm{CH}_{3}$ ), 30.0 (4-C), 30.5 (2'-C), 52.9 (2-C), 65.4 (1'-C), 80.1 (quat., $t$-Boc C), $155.5\left(\mathrm{NCO}_{2}\right.$ ), 172.3 (quat., 1-C), 177.0 (quat., 5-C); IR cm ${ }^{-1} 3357$ (N-H), 2962 (broad, O-H), 1709 (broad, $\mathrm{C}=\mathrm{O}), 1367(\mathrm{C}-\mathrm{N}), 1160(\mathrm{C}-\mathrm{O})$; Anal. calculated for $\mathrm{C}_{14} \mathrm{H}_{25} \mathrm{NO}_{6}\left(\mathrm{M}_{\mathrm{r}} 303.36\right) \mathrm{C} 55.43, \mathrm{H} 8.31, \mathrm{~N}$ $4.62 \%$; Found C 55.57, H 8.19, N $4.78 \%$; ESI MS $326.2\left[\mathrm{MNa}^{+}\right]$. 
Eur. J. Med Chem. 109 (2016) 206-215.

\subsection{General method for preparation of compounds $8 \boldsymbol{8}-\boldsymbol{c}$}

Compounds 7a-c were dissolved in dry DCM $(1 \mathrm{~g}$ in $50 \mathrm{~mL})$ under nitrogen. To this was added triethylamine (1 mol equivalent), HOBt (1 mol equivalent) and 1,3-diisopropylcarbodiimide ( 1 mol equivalent)and the mixture was stirred, at $0^{\circ} \mathrm{C}$ for 15 minutes. Cysteamine hydrochloride (1 mol equivalent) was then added and the mixture stirred at $0^{\circ} \mathrm{C}$ for 45 minutes, then at room temperature overnight. The solution was filtered and the combined organic layers were washed with $10 \% \mathrm{w} / \mathrm{v}$ potassium carbonate, $10 \% \mathrm{w} / \mathrm{v}$ citric acid and water, and then dried over magnesium sulfate. The resulting solution was concentrated under reduced pressure to afford the crude product. Purification by column chromatography (petrol/ethyl acetate as eluent) on silica was carried out to obtain the corresponding pure compound as a white solid 8a-c.

\subsubsection{2-(S)-tert-Butoxycarbonylamino-4-(2-mercapto-ethylcarbamoyl)-butyric acid butyl ester (8c)}

Following the procedure described in 4.3 , the reaction of compound $7 \mathrm{c}(0.74 \mathrm{~g}, 2.44 \mathrm{mmol})$ with cysteamine hydrochloride gave product $8 \mathrm{c}(0.62 \mathrm{~g}, 70 \%)$ : Mp 62-63 ${ }^{\circ} \mathrm{C} ;{ }^{1} \mathrm{H} \mathrm{NMR}(300 \mathrm{MHz}$, $\left.\mathrm{CDCl}_{3}\right) \delta_{\mathrm{H}} 0.94\left(\mathrm{t}, J=7.2 \mathrm{~Hz}, 3 \mathrm{H}, 4^{\prime}-\mathrm{CH}_{3}\right), 1.3(\mathrm{t}, J=6.5 \mathrm{~Hz}, 1 \mathrm{H}, \mathrm{SH}), 1.31$ (sextet, $J=7.2 \mathrm{~Hz}$, 2H, 3'- $\mathrm{CH}_{2}$ ), $1.43\left(\mathrm{~s}, 9 \mathrm{H}, t-\mathrm{Boc}_{3} \mathrm{CH}_{3}\right), 1.65$ (quintet, $\left.J=7.2 \mathrm{~Hz}, 2 \mathrm{H}, 2^{\prime}-\mathrm{CH}_{2}\right), 1.97\left(\mathrm{~m}, 1 \mathrm{H}, 3-\mathrm{CH}_{\mathrm{a}}\right.$ ), $2.20\left(\mathrm{~m}, 1 \mathrm{H}, 3-\mathrm{CH}_{\mathrm{b}}\right), 2.41\left(\mathrm{dd}, J=16.5\right.$ and $\left.6.8 \mathrm{~Hz}, 1 \mathrm{H}, 4-\mathrm{CH}_{\mathrm{a}}\right), 2.50(\mathrm{dd}, J=16.5$ and $6.8 \mathrm{~Hz}, 1 \mathrm{H}$, $\left.4-\mathrm{CH}_{\mathrm{b}}\right), 2.62\left(\mathrm{q}, J=6.5 \mathrm{~Hz}, 2 \mathrm{H}, 8-\mathrm{CH}_{2}\right), 3.36\left(\mathrm{q}, J=6.5 \mathrm{~Hz}, 2 \mathrm{H}, 7-\mathrm{CH}_{2}\right), 4.07(\mathrm{t}, J=7.2 \mathrm{~Hz}, 2 \mathrm{H}$, $\left.1^{\prime}-\mathrm{CH}_{2}\right), 4.33$ (m, 1H, 2-CH), 5.14 (br d, 1H, 2-CNH), 6.22 (br s, 1H, 6-NH); ${ }^{13} \mathrm{C}$ NMR (75 MHz, $\left.\mathrm{CDCl}_{3}\right) \delta_{\mathrm{C}} 10.35$ (4'-C), 21.9 (3'-C), 24.6 (8-C), 28.3 ( $t$-Boc $\mathrm{CH}_{3}$ ), 28.7 (3-C), 30.4 (8-C), 32.6 (4C), 38.5 (2'-C), 39.5(7-C), 53.3 (2-C), 67.1 (1'-C), 80.2 (quat., $t$-Boc C), 155.9 (quat., $\mathrm{NCO}_{2}$ ), 172.4 (quat., 5-C), 172.6 (quat., 1-C); IR cm ${ }^{-1} 3350(\mathrm{~N}-\mathrm{H}), 2422(\mathrm{SH}), 1721(\mathrm{C}=\mathrm{O}$, ester), $1683(\mathrm{C}=\mathrm{O}$, carbamate), $1649\left(\mathrm{C}=\mathrm{O}\right.$, amide), $1348(\mathrm{C}-\mathrm{N}), 1162(\mathrm{C}-\mathrm{O})$; Anal. calculated for $\mathrm{C}_{16} \mathrm{H}_{30} \mathrm{~N}_{2} \mathrm{O}_{5} \mathrm{~S}\left(\mathrm{M}_{\mathrm{r}}\right.$ 362.48): C 53.28, H 8.34, N $7.73 \%$; Found: C 53.41, H 8.18, N $7.78 \%$; ESI MS 385.2 [MNa ${ }^{+}$]. 
Eur. J. Med Chem. 109 (2016) 206-215.

\subsection{General method for preparation of compounds $\mathbf{9 a - c}$}

Compounds 8a-c and triethylamine (1 mol equivalent) were protected from moisture and stirred in dry THF ( $1 \mathrm{~g}$ in $30 \mathrm{~mL})$ at room temperature. To this acetic anhydride ( $1 \mathrm{~mol}$ equivalent) was added and the mixture stirred at $40^{\circ} \mathrm{C}$ overnight. The organic layer was washed with $10 \%$ potassium carbonate, brine and water, and then dried over magnesium sulfate. The resulting solution was concentrated under reduced pressure to afford the product crude product. Purification by column chromatography on silica (dichloromethane/methanol as eluent) on silica was required for obtaining the corresponding pure products 9a-c as a white solid.

4.4.1 4-(2-Acetylsulfanyl-ethylcarbamoyl)-2-(S)-tert-butoxycarbonylamino-butyric acid butyl ester $(9 c)$

Following the procedure described in 4.4, the reaction of compound $\mathbf{8 c}(1.00 \mathrm{~g}, 2.76 \mathrm{mmol}))$ with acetic anhydride gave product 9c $(0.62 \mathrm{~g}, 55 \%)$ : $\mathrm{Mp} 70-72{ }^{\circ} \mathrm{C} ;{ }^{1} \mathrm{H} \mathrm{NMR}\left(300 \mathrm{MHz}, \mathrm{CDCl}_{3}\right)$ $\delta_{\mathrm{H}} 0.93\left(\mathrm{t}, J=7.1 \mathrm{~Hz}, 3 \mathrm{H}, 4^{\prime}-\mathrm{CH}_{3}\right), 1.38$ (sextet, $\left.J=7.1 \mathrm{~Hz}, 2 \mathrm{H}, 3^{\prime}-\mathrm{CH}_{2}\right), 1.45\left(\mathrm{~s}, 9 \mathrm{H}, t-\mathrm{Boc}_{3} \mathrm{CH}_{3}\right.$, 1.63 (quintet, $\left.J=7.1 \mathrm{~Hz}, 2 \mathrm{H}, 2^{\prime}-\mathrm{CH}_{2}\right), 1.92\left(\mathrm{~m}, 1 \mathrm{H}, 3-\mathrm{CH}_{\mathrm{a}}\right), 2.15\left(\mathrm{~m}, 1 \mathrm{H}, 3-\mathrm{CH}_{\mathrm{b}}\right), 2.25(\mathrm{dd}, J=16.4$ and $\left.6.7 \mathrm{~Hz}, 1 \mathrm{H}, 4-\mathrm{CH}_{\mathrm{a}}\right), 2.29\left(\mathrm{dd}, J=16.4\right.$ and $\left.6.7 \mathrm{~Hz}, 1 \mathrm{H}, 4-\mathrm{CH}_{\mathrm{b}}\right), 2.35\left(\mathrm{~s}, 3 \mathrm{H}, 11-\mathrm{CH}_{3}\right), 3.04(\mathrm{t}, J$ $\left.=6.5 \mathrm{~Hz}, 2 \mathrm{H}, 8-\mathrm{CH}_{2}\right), 3.44\left(\mathrm{q}, J=6.5 \mathrm{~Hz}, 2 \mathrm{H}, 7-\mathrm{CH}_{2}\right), 4.14\left(\mathrm{t}, J=7.1 \mathrm{~Hz}, 2 \mathrm{H}, 1^{\prime}-\mathrm{CH}_{2}\right), 4.27(\mathrm{~m}$,

1H, 2-CH), 5.30 (br d, 1H, 2-CNH), 6.30 (br s, 1H,m, 6-NH); $\left.{ }^{13} \mathrm{C} \mathrm{NMR} \mathrm{(75} \mathrm{MHz,} \mathrm{CDCl}_{3}\right) \delta_{\mathrm{C}} 13.7$ (4'-C), 19.1 (3'-C), 28.4 (t-Boc $\mathrm{CH}_{3}$ ), 28.9 (3-C), 29.1(8-C), 30.6 (11-C) 30.6 (2'-C), 32.6 (4-C), 39.5 (7-C), 53.2 (2-C), 65.5 (1'-C), 80.1 (quat., t-Boc C), 155.9 (quat., $\mathrm{NCO}_{2}$ ), 172.1 (quat., 5-C), 172.3 (quat., 1-C), 196.0 (quat., 10-C); IR cm ${ }^{-1} 3320(\mathrm{~N}-\mathrm{H}), 1728(\mathrm{C}=\mathrm{O}$, ester), $1695(\mathrm{C}=\mathrm{O}$, thioester) $1686(\mathrm{C}=\mathrm{O}$, carbamate), $1648(\mathrm{C}=\mathrm{O}$, amide), $1367(\mathrm{C}-\mathrm{N}), 1164(\mathrm{C}-\mathrm{O})$; Anal. calculated for $\mathrm{C}_{18} \mathrm{H}_{32} \mathrm{~N}_{2} \mathrm{O}_{5} \mathrm{~S}\left(\mathrm{M}_{\mathrm{r}} 404.52\right) \mathrm{C} 53.44, \mathrm{H} 7.97, \mathrm{~N} 6.93 \%$; Found C 53.77, H 8.03, $6.95 \%$; ESI MS $427.2\left[\mathrm{MNa}^{+}\right]$. 
Eur. J. Med Chem. 109 (2016) 206-215.

\subsection{General method for preparation of compounds $\mathbf{1 0 a - c}$}

Compounds 8a-c were stirred in dry dichloromethane $(1 \mathrm{~g}$ in $30 \mathrm{~mL})$, under dry conditions and at room temperature. To this was added pyridine ( 1 mol equivalent) and benzoyl chloride (1 mol equivalent) and the mixture was stirred at room temperature overnight. The organic layer was washed with $10 \%$ potassium carbonate, brine and water, and then dried over magnesium sulfate. The resulting solution was concentrated under reduced pressure to afford the crude product. Column chromatography (petrol/ethyl acetate as eluent) on silica was required to obtain the corresponding pure product 10a-c as a white solid.

\subsubsection{4-(2-Acetylsulfanyl-ethylcarbamoyl)-2-(S)-tert-butoxycarbonylamino-butyric acid ethyl ester} $(10 a)$

Following the procedure described in 4.5 , the reaction of compound $\mathbf{8 a}(0.25 \mathrm{~g}, 0.75 \mathrm{mmol})$ with benzoyl chloride gave product 10a (0.08 g, $24 \%)$ : Mp 78-79 ${ }^{\circ} \mathrm{C} ;{ }^{1} \mathrm{H} \mathrm{NMR}\left(300 \mathrm{MHz}, \mathrm{CDCl}_{3}\right.$ ) $\delta_{\mathrm{H}} 1.26\left(\mathrm{t}, 3 \mathrm{H}, J=7.0 \mathrm{~Hz}, 2^{\prime}-\mathrm{CH}_{3}\right), 1.43\left(\mathrm{~s}, 9 \mathrm{H}, t-\mathrm{Boc} \mathrm{CH}_{3}\right), 1.93\left(\mathrm{~m}, 1 \mathrm{H}, 3-\mathrm{CH}_{\mathrm{a}}\right), 2.19(\mathrm{~m}, 1 \mathrm{H}, 3-$ $\left.\mathrm{CH}_{\mathrm{b}}\right), 2.26\left(\mathrm{dd}, J=16.6\right.$ and $\left.6.9 \mathrm{~Hz}, 1 \mathrm{H}, 4-\mathrm{CH}_{\mathrm{a}}\right), 2.29\left(\mathrm{dt}, J=16.6\right.$ and $\left.6.9 \mathrm{~Hz}, 1 \mathrm{H}, 4-\mathrm{CH}_{\mathrm{b}}\right), 3.25(\mathrm{t}$, $\left.J=6.3 \mathrm{~Hz}, 2 \mathrm{H}, 8-\mathrm{CH}_{2}\right), 3.55\left(\mathrm{q}, J=6.3 \mathrm{~Hz}, 2 \mathrm{H}, 7-\mathrm{CH}_{2}\right), 4.18\left(\mathrm{q}, J=7.0 \mathrm{~Hz}, 2 \mathrm{H}, 1^{\prime}-\mathrm{CH}_{2}\right), 4.27(\mathrm{~m}$, 1H, 2-CH), 5.28, (br d, 1H, 2-CNH), 6.44 (br s, 1H, 6-NH), 7.44 (t, J = 7.2 Hz, 2H, 13-CH), 7.59 (tt, $J=7.2$ and $1.4 \mathrm{~Hz}, 1 \mathrm{H}, 14-\mathrm{CH}), 7.96(\mathrm{dd}, J=7.2$ and $1.4 \mathrm{~Hz}, 2 \mathrm{H}, 12-\mathrm{CH}) ;{ }^{13} \mathrm{C} \mathrm{NMR}(75 \mathrm{MHz}$, $\left.\mathrm{CDCl}_{3}\right) \delta_{\mathrm{C}} 14.2\left(2^{\prime}-\mathrm{C}\right), 28.3\left(t-\mathrm{Boc}_{3} \mathrm{CH}_{3}\right), 28.6$ (3-C), 29.1(8-C), 32.6 (4-C), 39.6 (7-C), 53.1 (2-C), 61.5 (1'-C), 80.1 (quat., $t$-Boc $C$ ), $127.3(\mathrm{Ph} \mathrm{CH}), 128.7(\mathrm{Ph} \mathrm{CH}), 133.6(\mathrm{Ph} \mathrm{CH}), 136.8$ (quat., $11-$ C), 158.3 (quat., $\mathrm{NCO}_{2}$ ), 172.2 (quat., 5-C), 172.3 (quat., 1-C), 192.0 (quat., 10-C); IR cm ${ }^{-1} 3348$ $(\mathrm{N}-\mathrm{H}), 1734(\mathrm{C}=\mathrm{O}$, ester $), 1678(\mathrm{C}=\mathrm{O}$, carbamate $), 1662(\mathrm{C}=\mathrm{O}$, thioester $), 1644(\mathrm{C}=\mathrm{O}$, amide $)$, 1367 (C-N), 1160 (C-O), 777 and $688(\mathrm{Ar} \mathrm{C}-\mathrm{H})$; Anal. calculated for $\mathrm{C}_{21} \mathrm{H}_{30} \mathrm{~N}_{2} \mathrm{O}_{6} \mathrm{~S}\left(\mathrm{M}_{\mathrm{r}} 438.54\right) \mathrm{C}$ 57.51, H 6.90, N 6.39 \%; Found C 57.52, H 6.96, N 6.36 \%; ESI MS 461.2 [MNa $\left.{ }^{+}\right]$. 
Eur. J. Med Chem. 109 (2016) 206-215.

\subsection{General method for the preparation of compounds 11a-c}

Compounds 8a-c were stirred in dry dichloromethane $(1 \mathrm{~g}$ in $30 \mathrm{~mL})$, under dry conditions and at room temperature. To this was added pyridine (1 mol equivalent) and pivaloyl chloride (1 mol equivalent) and the mixture was stirred at room temperature overnight. The organic layer was washed with $10 \%$ potassium carbonate, brine and water, then dried over magnesium sulfate. The resulting solution was concentrated under reduced pressure to afford the crude product. Column chromatography (petrol/ethyl acetate as eluent) on silica and recrystallisation (ethyl acetate/hexane) was required to obtain the corresponding pure product 11a-c as a white solid.

4.6.1 2-(S)-tert-Butoxycarbonylamino-4-[2-(2,2-dimethyl-propionylsulfanyl)-ethylcarbamoyl]butyric acid propyl ester $(\mathbf{1 1 b})$

Following the procedure described in 4.6 , the reaction of compound $\mathbf{8 b}(0.20 \mathrm{~g}, 0.57 \mathrm{mmol})$ with pivaloyl chloride gave product $11 \mathbf{b}(0.10 \mathrm{~g}, 43 \%)$ : $\mathrm{Mp} 38-40{ }^{\circ} \mathrm{C} ;{ }^{1} \mathrm{H} \mathrm{NMR}\left(300 \mathrm{MHz}, \mathrm{CDCl}_{3}\right)$ $\delta_{\mathrm{H}} 0.94\left(\mathrm{t}, J=7.0 \mathrm{~Hz}, 3 \mathrm{H}, 3{ }^{\prime}-\mathrm{CH}_{3}\right), 1.24\left(\mathrm{~s}, 9 \mathrm{H}, 12-\mathrm{CH}_{3}\right), 1.44\left(\mathrm{~s}, 9 \mathrm{H}, t-\mathrm{Boc}_{3} \mathrm{CH}_{3}\right), 1.67$ (sextet, $J=$ $\left.7.0 \mathrm{~Hz}, 2 \mathrm{H}, 2 \mathrm{\prime}-\mathrm{CH}_{2}\right), 1.91\left(\mathrm{~m}, 1 \mathrm{H}, 3-\mathrm{CH}_{\mathrm{a}}\right), 2.15\left(\mathrm{~m}, 1 \mathrm{H}, 3-\mathrm{CH}_{\mathrm{b}}\right), 2.24(\mathrm{dd}, J=16.4$ and $6.8 \mathrm{~Hz}, 1 \mathrm{H}$, 4- $\left.\mathrm{CH}_{\mathrm{a}}\right), 2.26\left(\mathrm{dd}, J=16.4\right.$ and $\left.6.8 \mathrm{~Hz}, 1 \mathrm{H}, 4-\mathrm{CH}_{\mathrm{b}}\right), 3.00\left(\mathrm{t}, J=6.3 \mathrm{~Hz}, 2 \mathrm{H}, 8-\mathrm{CH}_{2}\right), 3.42(\mathrm{q}, J=6.3$ $\left.\mathrm{Hz}, 2 \mathrm{H}, 7-\mathrm{CH}_{2}\right), 4.10\left(\mathrm{t}, J=7.0 \mathrm{~Hz}, 2 \mathrm{H}, 1^{\prime}-\mathrm{CH}_{2}\right), 4.27(\mathrm{~m}, 1 \mathrm{H}, 2-\mathrm{CH}), 5.30$ (br d, 1H, 2-CNH), 6.35 (br s, 1H, 6-NH); ${ }^{13} \mathrm{C}$ NMR (75 MHz, $\mathrm{CDCl}_{3}$ ) $\delta_{\mathrm{C}} 10.3$ (3'-C), 21.9 (2'-C), 27.4 (12-C), 28.1 (3-C), 28.3 (t-Boc $\mathrm{CH}_{3}$ ), 29.0 (8-C), 32.6 (4-C), 39.6 (7-C), 46.5 (quat., 11-C), 53.1 (2-C), 67.1 (1'-C), 80.0 (quat., $t$-Boc $\mathrm{C}$ ), 155.8 (quat., $\mathrm{NCO}_{2}$ ), 172.0 (quat., 5-C), 172.3 (quat., 1-C), 207.1 (quat., 10C); IR cm $\mathrm{cm}^{-1} 3320(\mathrm{~N}-\mathrm{H}), 1678$ (broad, C=O), $1365(\mathrm{C}-\mathrm{N}), 1165$ (C-O); Anal. calculated for $\mathrm{C}_{20} \mathrm{H}_{36} \mathrm{~N}_{2} \mathrm{O}_{6} \mathrm{~S}\left(\mathrm{M}_{\mathrm{r}} 432.57\right) \mathrm{C} 55.53, \mathrm{H} 8.39$, N $6.48 \%$; Found C 55.30, H 8.65, N 6.55 \%; ESI MS $455.2\left[\mathrm{MNa}^{+}\right]$. 
Eur. J. Med Chem. 109 (2016) 206-215.

\section{General method for the preparation of prodrugs 1-3a-c}

Individually, compounds 9a-c, 10a-c and 11a-c were dissolved in a solution of $\mathrm{HCl}(2 \mathrm{M})$ in diethyl ether (Alfa Aesar) and stirred at room temperature. The reaction was monitored by TLC (petroleum ether/ethyl acetate).

Following the general procedure, compound 9a $(3.00 \mathrm{~g}, 3.97 \mathrm{mmol})$ was stirred in $\mathrm{HCl}(2 \mathrm{M})$ in diethyl ether overnight $(100 \mathrm{~mL})$. The white precipitate was collected, washed with diethyl ether and dried under vacuum (2.01 g, $80 \%)$ : Mp: 97-100 ${ }^{\circ} \mathrm{C} ;{ }^{1} \mathrm{H}$ NMR $\left(300 \mathrm{MHz}, \mathrm{d}_{6}\right.$-DMSO) $\delta_{\mathrm{H}} 1.21(\mathrm{t}$, $\left.J=7.0 \mathrm{~Hz}, 3 \mathrm{H}, 2^{\prime}-\mathrm{CH}_{3}\right), 2.10\left(\mathrm{~m}, 1 \mathrm{H}, 3-\mathrm{CH}_{\mathrm{a}}\right), 2.15\left(\mathrm{~m}, 1 \mathrm{H}, 3-\mathrm{CH}_{\mathrm{b}}\right), 2.25(\mathrm{dd}, J=16.6$ and $7.2 \mathrm{~Hz}$, $\left.1 \mathrm{H}, 4-\mathrm{CH}_{\mathrm{a}}\right), 2.29\left(\mathrm{dd}, J=16.6\right.$ and $\left.7.2 \mathrm{~Hz}, 1 \mathrm{H}, 4-\mathrm{CH}_{\mathrm{b}}\right), 2.30\left(\mathrm{~s}, 3 \mathrm{H}, 11-\mathrm{CH}_{3}\right), 2.74(\mathrm{t}, J=6.6 \mathrm{~Hz}$, 2H, 8- $\mathrm{CH}_{2}$ ), 3.29 (q, $\left.J=6.6 \mathrm{~Hz}, 2 \mathrm{H}, 7-\mathrm{CH}_{2}\right), 4.15\left(\mathrm{q}, J=7.0 \mathrm{~Hz}, 2 \mathrm{H}, 1^{\prime}-\mathrm{CH}_{2}\right), 4.20$ (m, 1H, 2-CH); ${ }^{13} \mathrm{C}$ NMR (75 MHz, d 6 -DMSO) $\delta_{\mathrm{C}} 14.7$ (2'-C), 23.2 (3-C), 28.8 (11-C), 30.5 (8-C), 32.6 (4-C), 39.5 (7-C), 53.1 (2-C), 61.5 (1'-C), 172.4 (quat., 5-C), 172.6 (quat., 1-C), 196.0 (quat., 10-C); IR cm ${ }^{-1}$ $3330\left(\mathrm{~N}^{+}-\mathrm{H}_{3}\right), 1656$ (broad, $\left.\mathrm{C}=\mathrm{O}\right), 1366(\mathrm{C}-\mathrm{N}), 1151(\mathrm{C}-\mathrm{O})$; Anal. calculated for $\mathrm{C}_{11} \mathrm{H}_{21} \mathrm{ClN}_{2} \mathrm{O}_{4} \mathrm{~S}$ $\left(\mathrm{M}_{\mathrm{r}} 312.81\right) \mathrm{C}$ 42.24, H 6.77, N $8.96 \%$; Found C 42.08, H 6.53, N 8.74 \%; HRMS calculated for $\left[\mathrm{C}_{11} \mathrm{H}_{21} \mathrm{~N}_{2} \mathrm{O}_{4} \mathrm{~S}\right]^{+}$277.1217, found 277.1217.

\section{Cell lines}

HaCaT keratinocytes were commercially obtained from Cell Line Services. PT37 cells were donated by the Leuven University Hospital, Belgium. Cell lines were cultured in DMEM/F12 medium (Invitrogen) supplemented with $2 \mathrm{mM}$ L-glutamine (1\%, Sigma Aldrich), penicillinstreptomycin (1\%, Sigma Aldrich) and heat inactivated fetal calf serum (10\%, Biosera). Cell monolayers were maintained at $37{ }^{\circ} \mathrm{C}$ under an atmosphere containing $5 \%$ carbon dioxide.

\section{General method for MTT assay}

Prodrugs were dissolved in medium to give a starting concentration of $500 \mu \mathrm{g} / \mathrm{mL}$. In a 96 well plate, serial dilutions were carried out to give subsequent concentrations of $250,125,62.5$, 
Eur. J. Med Chem. 109 (2016) 206-215.

$31.25,15.625,7.81,3.91$ and $1.95 \mu \mathrm{g} / \mathrm{mL}$. Cells were exposed to the prodrugs for a period of 48 hours while incubated at $37{ }^{\circ} \mathrm{C}$ under $5 \%$ carbon dioxide. Following exposure, the prodrug containing medium was removed and the cells in the 96 well plates were rinsed with PBS. MTT $(0.5 \mathrm{mg} / \mathrm{mL}$ in PBS, $200 \mu \mathrm{L})$ was added to each well and incubated for two hours at $37{ }^{\circ} \mathrm{C}$ under $5 \%$ carbon dioxide. Upon removal of the dye, the cells were again washed with PBS before the addition of a solution of $90 \%$ isopropanol and $10 \%$ DMSO $(200 \mu \mathrm{L})$. The plates were incubated in the dark for 10 minutes and then the absorbance was recorded at $595 \mathrm{~nm}$ using a Teccan plate reader and Revelation software. $\mathrm{EC}_{50}$ values were calculated from the dose response curves by nonlinear regression analysis using GraphPad Prism ${ }^{\circledR}$. Cell survival was expressed as a percentage compared to control wells. Percentage survival value at each concentration represents 12 replicates, which were averaged and normalised to calculate the percentage survival.

\section{General method for Sirius T3 measurement of $p K_{a}$ and $\log P$}

To measure the $\mathrm{p} K_{\mathrm{a}}$, between 1-2 mg of test compound was weighed accurately into a vessel and placed into the Sirius $\mathrm{T} 3$ instrument for $\mathrm{pH}$ metric analysis. The $\mathrm{p} K_{\mathrm{a}}$ was computationally determined following the automated potentiometric acid-base titration over a $\mathrm{pH}$ range of 2 to 12 (mean of 3 titrations). For the automated pH-metric measurement of Log $\mathrm{P}$, an accurately weighed sample was dissolved in a two-phase water-octanol system (1:2), and titrated over a $\mathrm{pH}$ range (2 to 12). Log P results were obtained by computational process using the Sirius T3 software.

\section{General method for measurement of total cellular cysteamine content}

Test prodrugs were dissolved in culture medium to obtain the required concentration (20 $\mu \mathrm{M})$. Confluent cell monolayers were incubated with the prodrug-containing medium at $37^{\circ} \mathrm{C}$ for a defined time period $(0,2,6,16$ or 24 hours). Monolayers were harvested using trypsin-EDTA $(0.25 \%)$, re-suspended in growth medium and centrifuged for 5 minutes at $1000 \mathrm{rpm}$. The resulting cell pellets were washed with cold PBS with centrifugation at $1000 \mathrm{rpm}$ for a further five minutes. 
Eur. J. Med Chem. 109 (2016) 206-215.

The pellets were then re-suspended in sucrose $(400 \mu \mathrm{L}, 0.25 \mathrm{M})$ and sonicated before the suspension was centrifuged at $13,000 \mathrm{rpm}$ for ten minutes. Following pellet suspension, $10 \mu \mathrm{L}$ of the cell supernatant was added to a microplate (in triplicate). To this, was added $240 \mu \mathrm{L}$ Bradford reagent (Sigma Aldrich, Poole, UK) and the plate incubated for 5 minutes at $37^{\circ} \mathrm{C}$. The absorbance was then measured at $595 \mathrm{~nm}$. The protein concentration was determined by comparison to a calibration curve prepared using bovine serum albumin standards $(0.1-1.5 \mathrm{mg} / \mathrm{mL}$ protein $)$.

The resultant supernatant was stored at $-80^{\circ} \mathrm{C}$ until HPLC analysis. For HPLC analysis, cell supernatant $(150 \mu \mathrm{L}), 1$-octanol $(30 \mu \mathrm{L})$, sodium borohydride $(40 \mu \mathrm{L}, 4 \mathrm{M}$ in a solution of $0.1 \mathrm{M}$ $\mathrm{NaOH} / \mathrm{DMSO}(300 \mathrm{~mL} / \mathrm{L}))$ and $\mathrm{HCl}(30 \mu \mathrm{L}, 3 \mathrm{M}$ added dropwise) were added to a reaction vial and vortex mixed for 3 minutes. This was followed by the addition of N-ethylmorpholine (100 $\mu \mathrm{L}$, 1.6M), phosphate buffer $(100 \mu \mathrm{L}, 0.2 \mathrm{M})$ and CMQT $(20 \mu \mathrm{L}, 0.1 \mathrm{M})$, before mixing for a further 3 minutes. Lastly, glacial acetic acid $(50 \mu \mathrm{L}, 0.5 \mathrm{M})$ was added before HPLC analysis.

\section{Acknowledgments}

This work was made possible by funding provided by the Cystinosis Foundation UK, who had no involvement in the experimental design, analysis and interpretation of results, writing of the manuscript or decision to publish. Gratitude is expressed to Professor Elena Levtchenko and Dr Martine Besouw (Leuven University Hospital, Belgium), and Dr Martijn Wilmers (Nijmegen University, Netherlands), for the provision of cells, to Dr Stephen Waldek for his helpful suggestions on the manuscript, and to Barrie Thynne, Joy Otun, and Phillip Rolfe for their technical contributions. We also thank the EPSRC UK National Mass Spectrometry Facility at Swansea University for providing accurate mass measurements.

\section{References}

1. Gahl, W.A.; Thoene, J.G.; Schneider, J.A. Cystinosis. New Eng. J. Med. 2000, 347, 111-121. 
Eur. J. Med Chem. 109 (2016) 206-215.

2. Nesterova, G.; Gahl, W. Nephropatic cystinosis: Late complications of a multisystemic disease. Ped. Nephrol. 2008, 23, 863-878.

3. Manz, F.; Gretz, N. Progression of chronic renal faluire in a historical group of patients with nephropathic cystinosis. European collaborative study on cystinosis. Ped. Nephrol. 1994, 8, 466471.

4. Gahl, W.A.; Balog, J.Z.; Kleta, R. Nephropathoc cystinosis in adults: natural history and effects of oral cysteamine therapy. Ann. Intern. Med. 2007, 147, 242-250.

5. Dohil, R.; Newbury, R.O.; Sellers, Z.M.; Deutsch, R.; Schneider, J.A. The evaluation and treatment of gastrointestinal disease in children with cystinosis receiving cysteamine. J. Peds. 2003, 143, 224-230.

6. Besouw, M.; Blom, H.; Tangerman, A.; de-Graff-Hess, A.; Levtchenko, E. The origin of halitosis in cystinotic patients due to cysteamine treatment. Mol. Gen. Metab. 2007, 91, 228-233.

7. Bouazza, N.; Treluyer, J.M.; Ottolenghi, C.; Urien, S.; Deschenes, G.; Ricquier, D.; Niaudet, P.; Chadefaux-Vekemans, B. Population pharmacokinetics and pharmacodynamics of cysteamine in nephropathic cystinosis patients. Orphanet J. Rare. Dis. 2011, 6, 86-94

8. Levtchenko, E.N.; van Dael, C.M.; de Graaf-Hess, A.C.; Wilmer, M.J.G.; van den Heuvel, L.P.; Monnens, L.A.; Blom, H.J. Strict cysteamine dose regimen is required to prevent nocturnal cystine accumulation in cystinosis. Ped. Nephrol. 2006, 21, 110-113.

9. Langman, C.B.; Greenbaum, L.A.; Sarwal, M.; Grimm, P.; Niaudet, P.; Deschénes, G.; Cornelissen, E.; Morin, D.; Cochat, P.; Matossian, D.; Gaillard, S.; Bagger, M.J.; Rioux, P. A randomized controlled crossover trial with delayed-release cysteamine bitartrate in nephropathic cystinosis: Effectiveness on white blood cell cysteine levels and comparison of safety. Clin. J. Am. Soc. Nephrol. 2012, 7, 1112-1120.

10. Besouw, M.T.; Bowker, R.; Duterte, J.P.; Emma, F.; Gahl, W.A.; Greco, M.; Lilien, M.R.; McKiernan, J.; Nobili, F.; Schneider, J.A.; Skovby, F.; van den Heuvel, L.P.; Van't Hoff, W.G.; Levtchenko, E.N. Cysteamine toxicity in patients with cystinosis. J. Peds. 2011, 159, 1004-1011. 
Eur. J. Med Chem. 109 (2016) 206-215.

11. Borrell-Pages, M.; Canals, J.M.;Cordelieres, F.P.; Parker, J.A.; Pineda, J.R.; Grange, G.;Bryson, E.A., Guillermier, M.; Hirsch, E.; Hantraye, P.; Cheetham, M.E.; Neri, C.; Alberch, J.; Brouillet, E.; Saudou, F.; Humbert, S. Cystamine and cysteamine increase brain levels of BDNF in Huntington disease via HSJ1b and transglutaminase. J. Clin Invest. 2006, 116, 1410-1424.

12. Dedeoglu, A.; Kubilus, J.K.; Jeitner, T.M.; Matson, S.A.; Bogdanov, M.; Kowall, N.W.; Matson, W.R.; Cooper, A.J.L.; Ratan, R.R.; Beal, M.F.; Hersch, S.M.; Ferrante, R.J. Therapeutic Effects of Cystamine in a Murine Model of Huntington's Disease. J. Neurosci. 2002, 22, 8942-8950

13. Charrier, C.;Rodger, C.; Robertson, J.; Kowalczuk, A.;Shand, N.; Fraser-Pitt, D.; Mercer, D.; O’Neil, D. Cysteamine (Lynovex $\left.{ }^{\circledR}\right)$, a novel mucoactive antimicrobial \& antibiofilm agent for the treatment of cystic fibrosis. Orphanet J. Rare Dis. 2014, 9, 189-200.

14. De Stefano, D.; Villella, V.R.; Esposito, S.; Tosco, A.; Sepe, A.; De Gregorio, F.; Salvadori, L.; Grassia, R.; Leone, C.A.; De Rosa, G.; Maiuri, M.C.; Pettoello, M.M.; Guido, S.; Bossi, A.; Zoli, A.; Venerando, A.; Pinna, L.A.; Mehta, A.; Bona, G.; Kroemer, G.; Maiuri, L.; Raia, V. Restoration of CFTR function in patients with cystic fibrosis carrying the F508del-CFTR mutation. Autophagy. 2014, 10, 2053-2074.

15. Devereux, G.; Fraser-Pitt, D.; Roberston, J.; Devlin, E.; Mercer, D.; O'Neil, D. Cysteamine as a Future Intervention in Cystic Fibrosis Against Current and Emerging Pathogens: A Patient-based ex vivo Study Confirming its Antimicrobial and Mucoactive Potential in Sputum. EBioMed. 2015, 2, $1507-1512$.

16. Dohil, R.; Schmeltzer, S.; Cabrera, B.L.; Wang, T.; Durelle, J.; Duke, K.B.; Schwimmer, J.B.; lavine, J.E. Enteric-coated cysteamine for the treatment of paediatric non-alcoholic fatty liver disease. Ailment Pharmacol. Ther. 2011, 33, 1036-1034.

17. Okamura, D.M.; Bahrami, N.M.; Ren, S.; Pasichnyk, K.; Williams, J.M.; Gangoiti, J.A; LopezGuisa, J.M.; Yamaguchi, I.; Barshop, B.A.; Duffield, J.S.; Eddy, A.A. Cysteamine modulates oxidative stress and blocks myofibroblast activity in CKD. J. Am. Soc. Nephrol. 2014, 25, 43-54. 
Eur. J. Med Chem. 109 (2016) 206-215.

18. Pisoni, R.L.; Park, G.Y.; Velilla, V.Q.; Thoene, J.G. Detection and characterization of a transport system mediating cysteamine entry into human fibroblast lysosomes. Specificity for aminoethylthiol and aminoethylsulfide derivatives. J. Biol. Chem. 1995, 270, 1179-1184

19. Jezegou, A.; Llinares, E.; Anne, C.; Kieffer-Jaquinod, S.; O’Regan, S.; Aupetit, J.; Chabli, A.; Sagne, C.; Debacker, C.; Chadefaux-Vekemans, B.; Journet, A.; Andre, B.; Gasnier, B. Heptahelical protein PQLC2 is a lysosomal cationic amino acid exporter underlying the action of cysteamine in cystinosis therapy. Proc. Nat. Aacd. Sci. 2012, 109, E3434-E3443.

20. Liu, B.; Du, H.; Rutkowski, R.; Gartner, A.; Wang, X. LAAT-1 is the lysosomal lysine/arginine transporter that maintains amino acid homeostasis. Science. 2012, 337, 351-354.

21. Anderson, R.J.; Cairns, D.; Cardwell, W.A.; Case, M.; Groundwater, P.W.; Hall, A.G.; Hogarth, L.; Jones, A.L.; Meth-Cohn, O.; Suryadevara, P.; Tindall, A.; Thoene, J.G. Design, Synthesis and Initial in vitro Evaluation of Novel Prodrugs for the Treatment of Cystinosis. Lett. Drug Des. Discov. 2006, 3, 336-345.

22. Testa, B.; Mayer, J.M. Hydrolysis in Drug and Prodrug Metabolism; Wiley: Zurich, 2003; pp 236-365.

23. Laizure, S.C.; Herring, V.; Hu, Z.; Witbrodt, K.; Parker, R.B. The role of human carboxylesterases in drug metabolism: Have we overlooked their importance? Pharmacotherapy. 2013, 33, 210-222.

24. Redinbo, M.R.; Potter, P.M. Mammalian carboxylesterases: From drug targets to protein therapeutics. Drug Discov. Today. 2005, 10, 313-325.

25. Guarino, V.R. The Molecular Design of Prodrugs by Functional Groups. In Prodrugs and Targeted Delivery: Towards Better ADME Properties; Rautio. J.; Mannhold, R.; Kubinyi, H.; Folkers, G., Eds.; Wiley: Weinheim, 2011; pp 31-111.

26. Ramsay, E.E.; Decollogne, S.; Joshi, S.; Corn, A.; Apte, M.; Pompella A ; Hogg, P..; Dilda, P.J. Employing pancreatic tumor $\gamma$-glutamyltransferase for therapeutic delivery. Mol. Pharmacol. 2014, $11,1500-1511$. 
Eur. J. Med Chem. 109 (2016) 206-215.

27. Rosalki, S.B. Gamma-glutamyl transpeptidase. In Advances in Clinical Chemistry, vol. 17; Bodanski, O.; Latner, A.L., Eds.; Academic Press: New York, London, 1975; pp 53-107.

28. Magnan, S.D.J.; Shirota, F.N.; Nagasawa, H.T. Drug latentiation by gamma-glutamyl transpeptidase. J. Med. Chem. 1982, 25, 1018-1021.

29. Wickham, S.; West, M.B.; Cook, P.F.; Hanigan, M.H. Gamma-glutamyl compounds: substrate specificity of gamma-glutamyl transpeptidase enzymes. Anal. Biochem. 2011, 414, 208-214.

30. Curto, K.A.; Sweeney, W.E.; Avner, E.D.; Piesco, N.P.; Curthoys, N.P. Immunocytochemical localization of gamma-glutamyltranspeptidase during fetal development of mouse kidney. $J$. Histochem. Cytochem. 1988, 36, 159-166.

31. Garvey, T.Q.; Hyman, P.E.; Isselbacher, K.H. Gamma-glutamyl transpeptidase of rat intestine: localization and possible role in amino acid transport. Gastroenterol. 1976, 71, 778-785.

32. Sanchez del Pino, M.M.; Hawkins, R.A.; Peterson, D.R. Biochemical discrimination between luminal and abluminal enzyme and transport activities of the blood-brain barrier. J. Biol. Chem. 1995, 270, 14907-14912.

33. Wilk, S.; Mizoguchi, H.; Orlowski, M. N-acyl-gamma-glutamyl derivatives of sulfamethoxazole as models of kidney-selective prodrugs. J. Pharmacol. Exp. Ther. 1980, 212, 167-172.

34. Wilk, S.; Mizoguchi, H.; Orlowski, M. gamma-Glutamyl dopa: a kidney-specific dopamine precursor. J. Pharmacol.Exp. Ther. 1978, 206, 227-232.

35. Mossman, T. Rapid colorimetric assay for cellular growth and survival: application to proliferation and cytotoxicity assays. J. Immunol. Methods. 1983, 65, 55-63.

36. Bald, E.; Glowacki, R. 2-Chloro-1-methylquinoliniumtetrafluoroborate as an effective and thiol specific UV-tagging reagent for liquid chromatography. J. Liq. Chrom. Rel. Technol. 2001, 24, 1323-1339.

37. Wilmer, M.J.; de Graaf-Hees, A.; Blom, H.J.; Dijkman, H.B.; Monnens, L.A.; van den Heuvel, L.P.; Levtchenko, E.N. Elevated oxidized glutathione in cystinotic proximal tubular epithelial cells. Biochem. Biophys. Res. Commun. 2005, 337, 610-614. 
Eur. J. Med Chem. 109 (2016) 206-215.

38. Khomenko, T.; Kolodney, J.; Pinto, J.T.; McLaren, G.D.; Deng, X.; Chen, L.; Tolstanova, G.; Paunovic, B.; Krasnikov, B.F.; Hoa, N.; Cooper, A.J.L.; Szabo, S. New mechanistic explanation for the localization of ulcers in the rat duodenum: Role of iron and selective uptake of cysteamine. Arch. Biochem. Biophys. 2012, 525, 60-70.

39. Svensson, B.E.; Lindvall, S. Myeloperoxidase-oxidase oxidation of cysteamine. Biochem. J. 1988, 249, 521-530.

40. Molina, M.T.; de Valle, C.; Escribano, A.M.; Ezquerrsa, J.; Pedregal, C. Regioselective ring opening of chiral N-Boc protected pyroglutamate and pyroaminoadipate ethyl esters with heteronucleophiles. Tetrahedron. 1993, 49, 3801-3808.

\section{Table of Content Graphic}

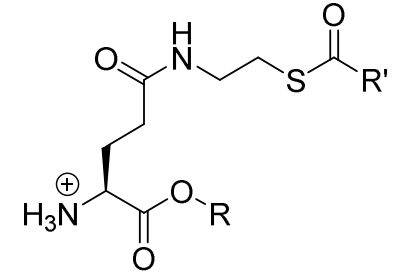

Diacylated $\gamma$-glutamylcysteamine prodrugs (i) (Thio)ester hydrolysis in the blood and/or liver<smiles>N[C@@H](CCC(=O)NCCS)C(=O)[O-]</smiles>

$\gamma$-glutamylcysteamine (ii) $\gamma$-glutamyl amide hydrolysis by GGT<smiles>[NH3+]CCS</smiles>

Cysteamine 